\title{
IDENTIFICATION OF THE BACTERIAL COMMUNITY RESPONSIBLE FOR DECONTAMINATING ELEME PETROCHEMICAL INDUSTRIAL EFFLUENT USING 16S rDNA PCR DENATURING GRADIENT GEL ELECTROPHORESIS
}

\author{
C. U. Ajuzie1,* and E. I. Atuanya ${ }^{2}$ \\ 1DEPARTMENT OF BIOLOGICAL SCIENCES, ACHIEVERS UNIVERSITY, OWO, ONDO STATE, NIGERIA \\ 2DEPARTMENT OF MicRoBiology, FACULTY OF LIFE SCIENCES, UNIVERSITY OF BENIN, NIGERIA \\ E-mail addresses: 1 ajuziech@gmail.com,2atuei@gmail.com
}

\begin{abstract}
Identification of bacteria community responsible for decontaminating Eleme petrochemical industrial effluent using 16S PCR denaturing gradient gel electrophoresis (DGGE) was determined. Gene profiles were determined by extracting DNA from bacterial isolates and amplified by polymerase chain reaction (PCR) using $16 S$ rDNA eubacterial primers with a GC clamp. PCR amplified DNA was separated by Denaturing Gradient Gel Electrophoresis (DGGE) analysis. Comparative evaluation of primers for PCR amplification of DNA revealed that V6V8F and V6V8R primers were most suitable for amplification DNA. Denaturing gradient gel ratio of $20 \%: 80 \%$ was most suitable for differentiation of bacterial profiles. Sequencing and phylogenetic analysis of DGGE products were successful displaying 88\% -100\% similarity and homology to Roseococcus sp. LW5(FM956480.1). Dendograms and similarity matrix revealed $81.5 \%-100 \%$ from sampling points.
\end{abstract}

Key words: Petrochemical industrial effluent; polymerase chain reaction; Denaturing gradient gel electrophoresis (DGGE); Deoxyribonucleicacid (DNA);Primers

\section{INTRODUCTION}

The Company processes natural gas liquids, which occur in association with crude oil, made up of paraffins and olefins that can be combined to form desired petrochemicals. These products that serve as raw materials in the downstream industries for the production of plastics and other related products come out as crystalline thermophilic resins in the form of pellets. Additives, including antioxidants, stabilizers are added to polymers just before pelletizing to improve its resistance and quality. These activities generate different forms of wastes, which eventually end up in the environment with or without treatment. The Eleme Petrochemical industrial effluent take various forms which include; processed wastewater (raw effluent);clarified water (effluent undergoing treatment); retention pond gate(treated waste water) and receiving river. So also are the wastewaters generated as a result of office or domestic activities in the company (domestic wastewater or sewage) [1].

Studies on Eleme Petrochemical effluents have revealed that although effluents from Eleme
Petrochemical Company Limited generally contain relatively low concentrations of pollutants in the water and sediment, accumulation of these pollutants overtime can be fatal to aquatic and human life [2].

The unabated accumulation of these pollutants overtime in aquatic and terrestrial environments may be fatal to wildlife and man. This therefore makes imperative the need for early resolution of the problem of treatment for Eleme petrochemical effluent[2].This dire need in recent times has found microorganisms quite instrumental. Microorganisms have been implicated in showing strong ability to biotreat petrochemical effluents. The potentials of microorganisms to catabolize and metabolize xenobiotic compounds have been recognized as potentially effective means of toxic and hazardous wastes disposal.

\section{MATERIALS AND METHODS}

Eleme Petrochemical Company Limited (EPCL) is situated in Eleme, Rivers state in the oil-rich Niger Delta area of Nigeria. It was established by the Federal 
Government of Nigeria in 1988.The major feedstock used in the company is delivered to it in liquid form via pipeline from the liquefied natural gas (LNG) plant located at Obiafu/Obrikom in Rivers state. The feedstock is free from methane, but composed of ethane, propane and butane with minor quantities of pentane and heavier hydrocarbons. The major products of the company are low density and linear low density polyethylene (LLDPE), polypropylene (PP), vinyl chloride monomer, butane and mixture of other olefins. Effluents are usually treated with sulphuric acid, caustic soda, alum, urea, Di-ammonium phosphate, anionic polyelectrolyte and calcium hypochlorite. Thereafter, the treated effluent is directly discharged into receiving river bodies.

The Eleme River in Eleme kingdom took its source at Oyigbo and flows down Agbonchia farm settlement, Njuru, Okerewa and Aluto at which point the petrochemical effluent is discharged into it before entering into tidal creek by NNPC housing estate Aleto and flows down to Okrika. The river passes through sparse vegetation and its course flows across many roads and as such receives storm water runoffs from roads too.

\subsection{Sample collection}

Samples were collected once a month between July 2007 and March 2008.Water samples were collected with a 2- liter plastic hydro-bios water sampler and transferred to clean 2-liter polyethylene containers and $250 \mathrm{ml}$ capacity borosilicate glass bottles as described by [1]. The effluent samples include the process wastewater(PWW) (untreated effluent), clarified water(CW),retention pond gate (RPG), which is the industrial effluent that has undergone both chemical and biological treatment to eliminate or reduce waste contents to acceptable levels and the receiving river(RR) of Eleme Kingdom. These were collected in polyethylene containers and borosilicate bottles of the same capacity [1]. They were rinsed several times with water or effluent samples at the point of collection. The samples were transported to the laboratory using iced packed coolers after appropriate labeling.

\subsection{DNA extraction from petrochemical industrial effluent}

Zymoclean $^{\mathrm{TM}}$ Gel DNA Recovery Kit (catalog nos.D4001, D4002, D4007\&D4008) was used for extraction of DNA from effluent samples. Effluent samples were filtered using microfunnel ${ }^{\mathrm{TM}}$ filter unit with super $\mathrm{R}$ membrane $(0.24 \mu \mathrm{m})$. The effluent samples were collected from the processed wastewater (PWW), clarifier (CW), retention pond gate (RPG) and receiving river(RR) from Eleme petrochemical industrial effluent. The effluent was filtered in triplicates of $200 \mathrm{ml}$ each. After filtration, the filter membrane was aseptically removed. Using sterile forceps, the filter membrane was picked and inserted into a water bead tube. Four milliliters $(4 \mathrm{ml})$ of bead solution was added to the water bead tube and vortexed for 30seconds.Five hundred micronlitre $(500 \mu \mathrm{l})$ of solution WD1 was added to each bead tube and vortexed for 30 seconds to mix. The water beads were then secured firmly on a flatbed vortex pad with tape. It was then vortexed at maximum speed for 10 minutes taking care to make sure the tape does not loose. After vortexing, it was centrifuged at $2500 \times \mathrm{g}$ for 1 minute.The supernatant was then transferred to a clean $15 \mathrm{ml}$ centrifuge tube (about $3.2 \mathrm{ml}$ of supernatant was transferred).Six hundred microlitres of solution WD2 was then added to the supernatant and vortexed for 5 seconds. It was then incubated at $4^{\circ} \mathrm{C}$ for 5 minutes, the tubes were then centrifuged for 4 minutes at $2500 \mathrm{xg}$.Avoiding the pellet, the entire volume of supernatant was transferred into another clean $15 \mathrm{ml}$ centrifuge tube(approximately $4 \mathrm{ml}$ was recovered).Eight milliliter $(8 \mathrm{ml})$ of solution WD3 was added to the supernatant and vortexed for 5 seconds. The supernatants were then loaded into $50 \mathrm{ml}$ spin filter tubes and centrifuged at 2500xg for 2 minutes.The flow through was discarded. Three millilitres of solution WD4 was added and centrifuged for 3 minutes at $2500 \times \mathrm{g}$, flow through discarded. It was re-centrifuged for 5 minutes at $2500 \times \mathrm{g}$ and being careful not to splash liquid on the filter basket, the spin filter was placed into a new $50 \mathrm{ml}$ collection tube provided .Three millilitres of solution WD5 was directly added to the center of the filter membrane and tubes re-centrifuged for 2 minutes at $2500 \times$ g.The spin filter were then discarded. The DNA in the tube were then stored at $-20^{\circ} \mathrm{C}$.

\subsection{PCR amplification of $16 \mathrm{~S}$ rDNA for petrochemical industrial effluent bacterial isolates}

Different regions of the 16S rDNA were amplified with different primers in order to determine the primers that provided the best DGGE differentiation of the microbial community responsible for decontaminating petrochemical industrial effluent. 


\subsubsection{V3 PCR Amplification}

One set of primers amplifying the variable V3 region(V3F and V3R) as described by [3] was used to amplify $16 \mathrm{~S}$ rDNA from the petrochemical industrial effluent bacterial isolates. The V3 region of the $16 \mathrm{~S}$ rDNA was amplified using V3 Reverse primer(518Rprimer V3 16s MWG-Biotech,5'-ATT ACC GCG GCT GCT GG-3') and V3 Forward primer(338F-primer,5'ACT CCT ACG GGA GGC AGC AG-3') with a GC clamp(CGC CCG CCG CGC CCC GCG CCC GTC CCG CCG CCC G) [4] in order to increase DGGE separation. Amplification was performed in a programmable heating thermocycler(C1000 Thermal Cycler).

The reaction mixture $(50 \mu \mathrm{l}$ total volume for each sample) for the PCR was composed as follows: $25 \mu \mathrm{l}$ of $2 \times$ master $\operatorname{mix}(2 \times \mathrm{mm}), 0.2 \mu \mathrm{l}$ of forward and revise primers, $1.5 \mu$ l of template DNA and $23.3 \mu$ l of nuclease free water.PCR amplification was performed as follows:5 $\mathrm{min}$ at $94^{\circ} \mathrm{C}$ to denature template DNA,10 cycles decreasing by $1^{\circ} \mathrm{C}$ each round from $66^{\circ} \mathrm{C}$ primer annealing,20 cycles at $56^{\circ} \mathrm{C}$ for amplimer extension, 3 min at $72^{\circ} \mathrm{C}$, and then the final extension was carried out at $72^{\circ} \mathrm{C}$ for $10 \mathrm{~min}$.

The PCR product was analyzed by electrophoresis on 1\% TAE agarose (Agarose 3:1,Melford Laboratories Ltd., Ipswich,UK) gel containing ethidium bromide $(0.2 \mu \mathrm{g} / \mathrm{ml})$ in $1 \mathrm{x}$ TAE running (40Mm Tris base, $20 \mathrm{mM}$ acetic acid,1mM EDTA) at 75 volt for about $90 \mathrm{~min}$. Samples contained $10 \mu \mathrm{l}$ of PCR product and $2 \mu \mathrm{l}$ of loading dye (Promega).The gel was viewed under a UV transilluminator (GelDoc XR, Biorad) and the gel pictures were recorded by using the GelDoc system (The Quantity one 4.6.5 Basic software, USA).

\subsubsection{S PCR Amplification}

One set of primers amplifying the 16S rDNA fragments as described by [5] was also used. The $16 \mathrm{~S}$ rDNA fragments were amplified with primers $16 \mathrm{~S}$ forward primer(5'-AGA GTT TGA TYM TGG CTC AG-3') and 16S reverse primer(5'-ACG GYT ACC TTG TTA CGA CTT$\left.3^{\prime}\right)$. Amplification was performed in a programmable heating thermocycler (C1000 Thermal Cycler).

The reaction mixture $(50 \mu \mathrm{l}$ total volume for each sample) for the PCR was composed as follows: $25 \mu \mathrm{l}$ of Dream Taq ${ }^{\mathrm{TM} G r e e n}$ PCR Master $\operatorname{Mix}(2 \mathrm{x}), 2 \mu \mathrm{l}$ of forward and revise primers, $1 \mu \mathrm{l}$ of template DNA and $21 \mu \mathrm{l}$ of nuclease free water and $1 \mu \mathrm{l}$ of $\mathrm{MgCl}_{2}$.PCR amplification was performed as follows: $3 \mathrm{~min}$ at $95^{\circ} \mathrm{C}$ for initial denaturation of template DNA,1 cycle; $30 \mathrm{~s}$ at $95^{\circ} \mathrm{C}$ for denaturation, $30 \mathrm{~s}$ at $5^{\circ} \mathrm{C}$ for primer annealing, $1 \mathrm{~min}$ at $72^{\circ} \mathrm{C}$ for extension,25-40 cycles;and $15 \mathrm{~min}$ at $72^{\circ} \mathrm{C}$ for the final extension, I cycle.

The PCR product was analyzed by electrophoresis on 1\% TAE agarose(Agarose 3:1,Melford Laboratories Ltd., Ipswich, UK) gel containing ethidium bromide $(0.2 \mu \mathrm{g} / \mathrm{ml})$ in $1 \mathrm{x}$ TAE running $(40 \mathrm{Mm}$ Tris base, $20 \mathrm{mM}$ acetic acid,1mM EDTA) at 75 volts for about $90 \mathrm{~min}$. Samples contained $10 \mu \mathrm{l}$ of PCR product and $2 \mu \mathrm{l}$ of loading dye (Promega).The gel was viewed under a UV transilluminator (GelDoc XR, Biorad) and the gel pictures were recorded by using the GelDoc system (The Quantity one 4.6.5 Basic software, USA).

\subsubsection{V6-V8 PCR Amplification}

One set of primers amplifying the V6-V8 region of $16 \mathrm{~S}$ rDNA was also used as described by [6].The V6-V8 region was amplified with primers V6V8 forward primer(5'-AGC AGT AGG GAA TCT TCA-3') and V6V8 Reverse primer(5'ATT TCA CCG CTA CAC ATG-3') with a GC clamp(CGC CCG CCG CGC CCC GCG CCC GTC CCG CCG CCC G) [4]in order to increase DGGE separation. Amplification was performed in a programmable heating thermocycler (C1000 Thermal Cycler).

The reaction mixture $(50 \mu \mathrm{l}$ total volume for each sample) for the PCR was composed as follows: $25 \mu \mathrm{l}$ of Dream Taq ${ }^{\mathrm{TM} G r e e n}$ PCR Master $\operatorname{Mix}(2 \mathrm{x}), 2 \mu \mathrm{l}$ of forward and revise primers, $1 \mu$ l of template DNA and $20 \mu \mathrm{l}$ of nuclease free water and $2 \mu \mathrm{l}$ of $\mathrm{MgCl}_{2}$.PCR amplification was performed as follows: $2 \mathrm{~min}$ at $95^{\circ} \mathrm{C}$ for initial denaturation of template DNA,2 cycles; $30 \mathrm{~s}$ at $95^{\circ} \mathrm{C}$ for denaturation, 35 cycles; $40 \mathrm{~s}$ at $56^{\circ} \mathrm{C}$ for primer annealing, $1 \mathrm{hr}$ at $72^{\circ} \mathrm{C}$ for extension, and $5 \mathrm{~min}$ at $72^{\circ} \mathrm{C}$ for the final extension.

The PCR product was analyzed by electrophoresis on 1\% TAE agarose (Agarose 3:1,Melford Laboratories Ltd., Ipswich, UK) gel containing ethidium bromide $(0.2 \mu \mathrm{g} / \mathrm{ml})$ in $1 \mathrm{x}$ TAE running $(40 \mathrm{Mm}$ Tris base, $20 \mathrm{mM}$ acetic acid,1mM EDTA) at 75 volts for about $90 \mathrm{~min}$. Samples contained $10 \mu \mathrm{l}$ of PCR product and $2 \mu \mathrm{l}$ of loading dye (Promega).The gel was viewed under a UV transilluminator (GelDoc XR, Biorad) and the gel pictures were recorded by using the GelDoc system (The Quantity one 4.6.5 Basic software, USA).

\subsection{Denaturing gradient gel analysis (DGGE)}

Denaturing gradient gel electrophoresis (DGGE) was performed using a Bio-Rad D-Code Universal Mutation Detection System. All DGGE reagents were from Severn Biotechnology Ltd, Worcestershire, UK. Two different denaturing gradients 30\%:50\% and 20\%:80\% urea-formamide $[7,16]$ were used to make 
the denaturing solutions for DGGE gel in order to select the most appropriate denaturing gradient for microbial community decontaminating petrochemical industrial effluent.

Before making the gel,0\% denaturant solution and $100 \%$ denaturant solution were prepared. Zero percent denaturant solution contained 40\% acrylamide/bis,50X TAE buffer, and deionised water while $100 \%$ denaturant solution contained urea,50X TAE, $40 \%$ acrylamide/bis and deionised formamide (see appendix for constitution).

This analysis was started from preparing the sealing gel:1.5 ml of $0 \%$ denaturant solution, $13.5 \mu \mathrm{l}$ of $10 \%$ ammonium persulphate (APS), and $1.35 \mu \mathrm{l}$ of $\mathrm{N}, \mathrm{N}, \mathrm{N}, \mathrm{N}-$ tetramethyl-ethylenediamine (TEMED) were mixed and then $750 \mu \mathrm{l}$ was pipetted into each corner of the glass plates to seal it. For the 30\%:50\% denaturant gradient after $30 \mathrm{~min}$ of sealing of plates, high denaturant solution $(7.5 \mathrm{ml}$ of $0 \%$ denaturation solution, $7.5 \mathrm{ml}$ of $100 \%$ denaturant solution, $150 \mu \mathrm{l}$ of DGGE dye, $135 \mu \mathrm{l}$ of $10 \%$ APS and $13.5 \mu$ l of TEMED) and low denaturant solution $(10.5 \mathrm{ml}$ of $0 \%$ denaturing solution, $4.5 \mathrm{ml}$ of $100 \%$ denaturing solution, $135 \mu \mathrm{l}$ of $10 \%$ APS and $13.5 \mu \mathrm{l}$ of TEMED) were added into the glass plates using a gradient maker (Bio-Rad model 385).The 20\%:80\% denaturant gradient was prepared with high denaturant solution( $3 \mathrm{ml}$ of $0 \%$ denaturing solution, $12 \mathrm{ml} 100 \%$ denaturation solution, $150 \mu$ l of DGGE dye, $135 \mu \mathrm{l}$ of $10 \%$ APS and $13.5 \mu$ of TEMED) and low denaturant solution( $12 \mathrm{ml}$ of $0 \%$ denaturing solution, $3 \mathrm{ml} 100 \%$ denaturing solution, $135 \mu \mathrm{l}$ of $10 \%$ APS and $13.5 \mu \mathrm{l}$ of TEMED) added into plates also using the gradient maker (Bio-Rad model 385).After insertion of the 16well comb on each glass plates, the gel was left at room temperature for $1 \mathrm{hr}$ to solidify before storing overnight at $4^{\circ} \mathrm{C}$.

Samples containing equal amounts of PCR amplicons ( $20 \mu \mathrm{l}$ of PCR products $+20 \mu \mathrm{l}$ of loading dye) and marker $(10 \mu$ l of ladder $+10 \mu$ l of loading dye) were loaded into the gel wells. Electrophoresis was run in $1 \mathrm{x}$ TAE buffer at $60^{\circ} \mathrm{C}$,for $20 \mathrm{~min}$ at $20 \mathrm{~V}$ and subsequently for $16 \mathrm{~h}$ at $60 \mathrm{~V}$ [8].After electrophoresis, the gels were stained for $30 \mathrm{~min}$ with $2 \mathrm{ul}$ of Gelstar diluted in $20 \mu \mathrm{l}$ if $1 \mathrm{x}$ TAE. Stained gels were visualized in a GelDoc System (Bio-Rad).

\subsection{Excision, re-amplification and purification of DGGE bands}

DGGE bands were carefully excised on an UV transilluminator with a sterile scalpel and subsequently transferred to a sterile1.5 $\mathrm{ml}$ tube (Eppendorf tube) containing $20 \mu \mathrm{l}$ of TE buffer and stored at $4^{\circ} \mathrm{C}$ overnight to allow diffusion of the DNA. The samples were then centrifuged at $12,000 \mathrm{rpm}$ for $10 \mathrm{~min}$. One microlitre of the supernatant was subsequently used for re-amplification of the DNA fragment. The reamplification of DGGE products used the same PCR reaction mixture and conditions as stated above but without a GC-clamp. Electrophoresis was run at $75 \mathrm{~V}$ for $1 \mathrm{~h}$ using $5 \mu \mathrm{l}$ of re-amplified products on a $1 \%$ TAE agarose gel containing ethidium bromide $(0.2 \mu \mathrm{g} / \mathrm{ml})$ to check product recovery and to estimate product concentration. The gel was again viewed and images recorded using the GelDoc system. Distinct bands were cut out of the gel with sterile scalpel into sterile $1.5 \mathrm{ml}$ tubes and kept at $-20^{\circ} \mathrm{C}$ until use. Cut DNA were purified using a Zymoclean Gel DNA Recovery Kit (The Epigenetic Company; Cambridge, UK).The instructions of the kit were modified as follows:500 $\mu \mathrm{l}$ of ADB buffer added to each volume of gel. The sample was incubated at $55^{\circ} \mathrm{C}$ for $30 \mathrm{~min}$.The melted agarose solution was added into Zymo-spin column and put into a collection tube before centrifugation for 30seconds at 13,000 rpm. The collection tube was then emptied. Wash buffer $(200 \mu \mathrm{l})$ was added to the column and centrifuged for $30 \mathrm{sec}$ at $13,000 \mathrm{rpm}$.The step was repeated thrice. The Zymo-spin column was then placed into a new $1.5 \mathrm{ml}$ (Eppenndorf tube) and $10 \mu \mathrm{l}$ of nuclease-free water was added directly to the column matrix and re-centrifuged to elute the DNA. Finally, the purified DNA product was kept at $-20^{\circ} \mathrm{C}$ until use.

\subsection{DNA sequencing}

Ten microlitre $(10 \mu \mathrm{l})$ of eluted DNA was diluted in $10 \mu \mathrm{l}$ of nuclease free water, while the $16 \mathrm{~S} \mathrm{~V} 6 \mathrm{~V} 8 \mathrm{~F}$ primer was prepared with $2 \mathrm{pmol} / \mu \mathrm{l}$ concentration and sent to MWG Company in Germany (Eurofins MWG, Operon Sequencing Department, Anzinger Str.7a, 85560 Ebersberg, Germany) for sequencing. The result of DNA sequences were analyzed by using BLAST (Basic Local Alignment Search Tool) search programme.[17]

\section{RESULTS}

The results presented here deals with comparative evaluation of primers for pcr amplification of DNA from petrochemical industrial effluent isolates Plates 1-3 shows the results of three different sets of primers(16SF \& 16SR; V3F \& V3R \& V6-V8) stained 
on $1 \%$ agarose gel to determine the primers that will provide the best DGGE differentiation of bacterial isolates from petrochemical industrial effluent. V6V8F \& V6V8R primers enabled all the 16S rDNA fragments of bacterial isolates to be amplified (plate3) with the expected size of 500bp.V3F\&V3R had 200bp size (plate2) and 16S and 16SR (plate1) could not enable the isolates to all be amplified.

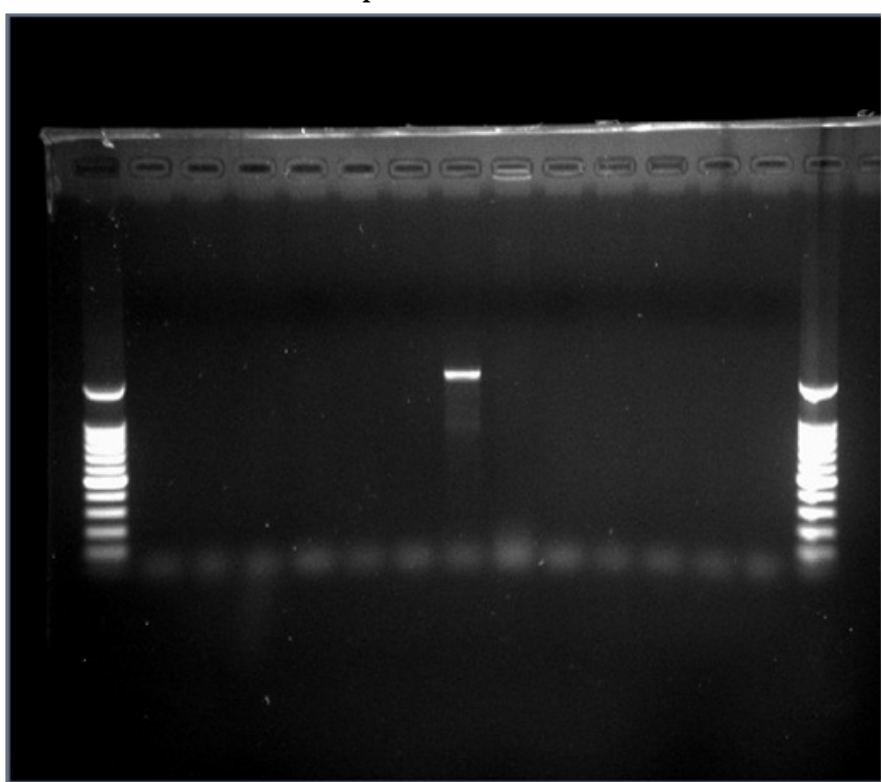

Plate 1: Ethidium bromide-stained 1\% agarose gel showing product size using $16 S F$ and $16 S R$ primers for amplification of $16 S$ region of I6S Rdna of bacterial isolates from petrochemical industrial effluent.

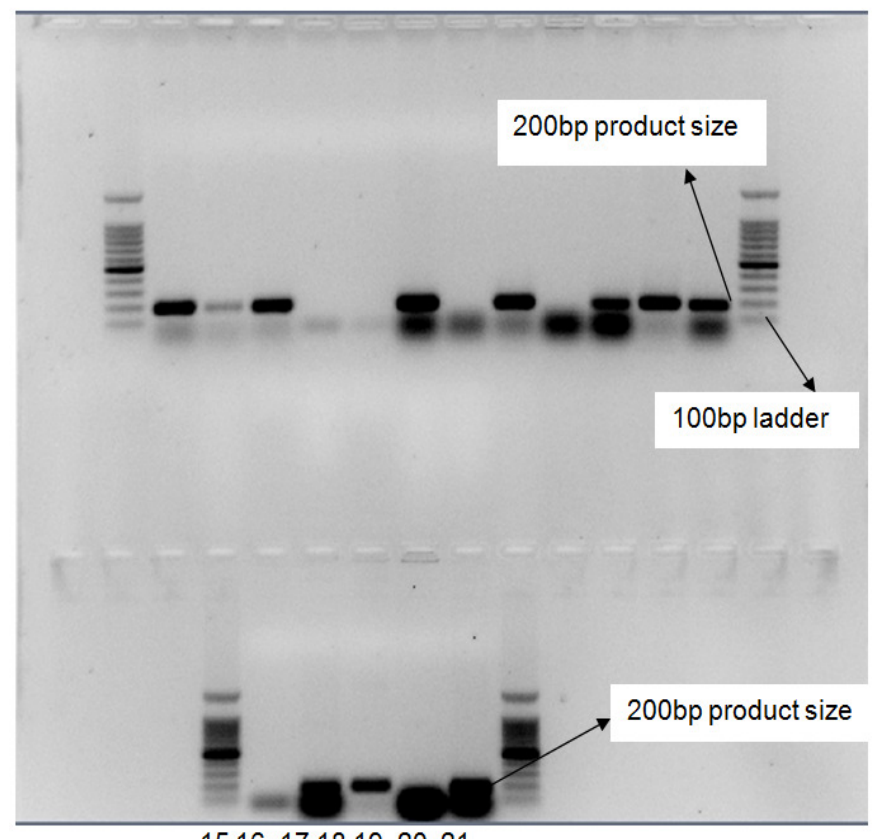

15161718192021

Plate 2: Ethidium bromide-stained 1\% agarosegel showing product size using V3F \&V3R primers for amplification of $V 3$ region of $16 S \mathrm{rDNA}$ of isolates from petrochemical industrial effluent.

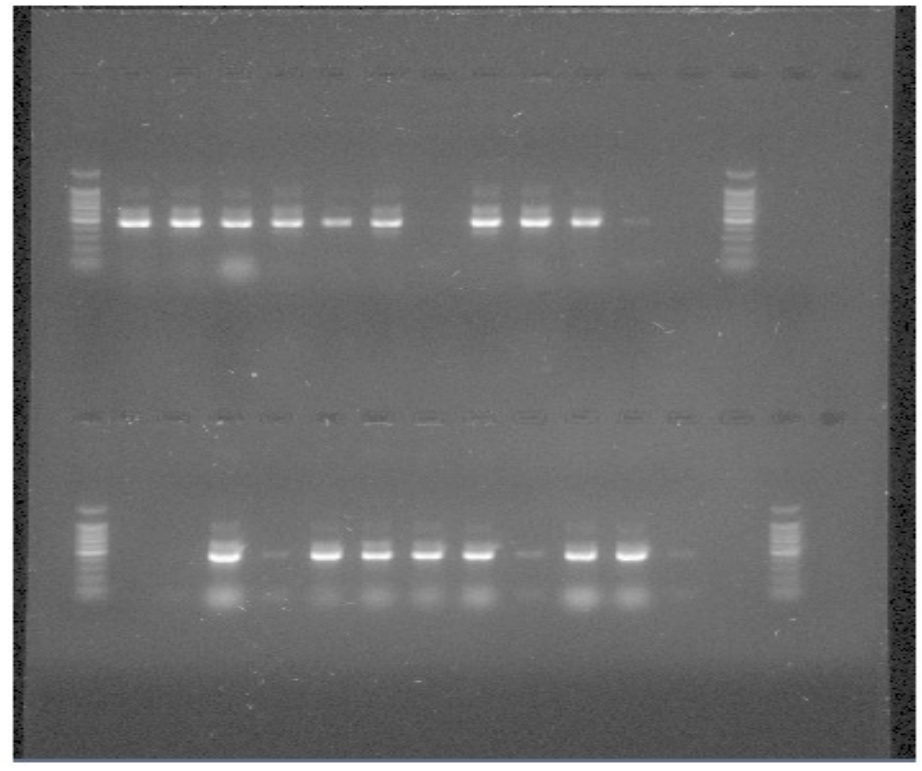

Plate 3: Ethidium bromide-stained 1\% agarose gel showing product size using V6-V8F\& V6-V8R primers for amplification of $V 6-V 8$ region of $16 S$ rDNA of isolates from petrochemical industrial effluent

3.1 Denaturing gradient gel analysis (DGGE) of 16s rDNA of bacterial community from petrochemical industrial effluent

Plates 4-7 shows the DGGE profiles of the PCR products different primers obtained from bacterial community from petrochemical industrial effluent using two denaturing gradients. Plate 4 shows PCR products from GCV3F and V3R primers run on $20 \%$ to $80 \%$ denaturing gradient, plate 5, PCR products of GCV6V8F and V6V8R primers run on $30 \%$ to $50 \%$ denaturing gradient and plates 6 and 7, PCR products from GCV6V8F and V6V8R primers on 20\%-80\% denaturing gradient. Plates 6 and 7 had a better DGGE differentiation pattern as compared to plates 4 and 5 .



Plate 4: 20\%:80\% DGGE fingerprints of PCR-amplified region using GCV3F and V3R of $16 S$ rDNA from effluent bacterial communities. Lanes:1-3, effluent samples from river; 4-6 effluent from clarifier, and 7and 8 samples from retention pond gate. 
$\begin{array}{lllllllllll}12 & 3 & 4 & 5 & 6 & 7 & 8 & 9 & 10 & 11 & 12\end{array}$

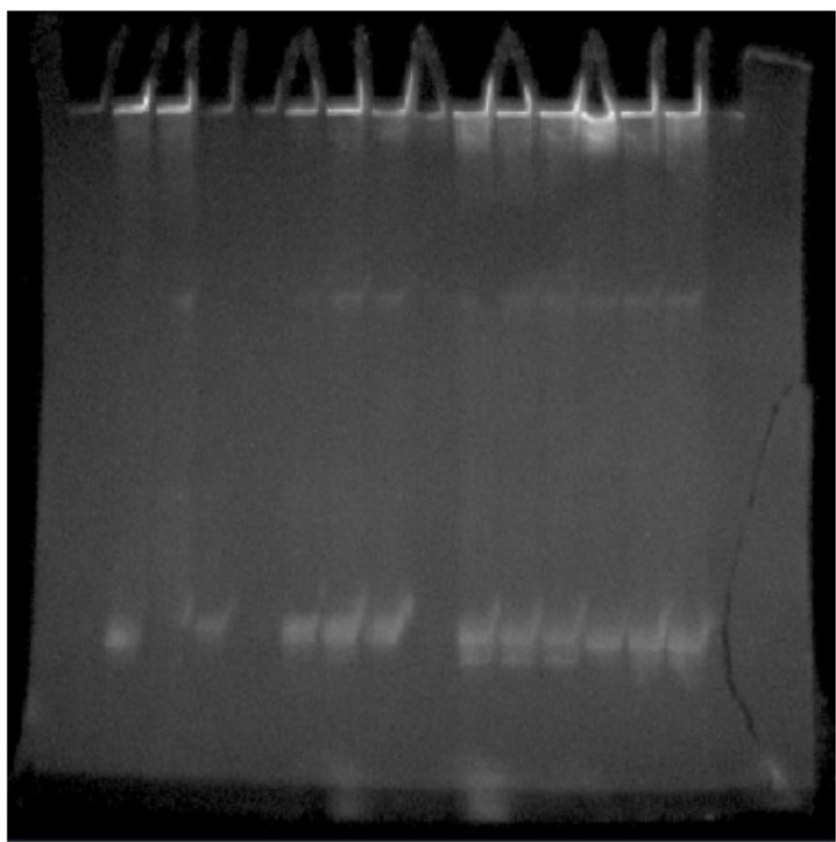

Plate 5: $30 \%: 50 \%$ DGGE fingerprints of PCR-amplified region using GCV6 -V8F and V6-V8R of $16 S$ rDNA from effluent bacterial communities. Lanes: 1-3, effluent samples from clarifier; 4-6samples from river; 7-9, samples from processed water and lanes 10-12, samples from retention pond gate.

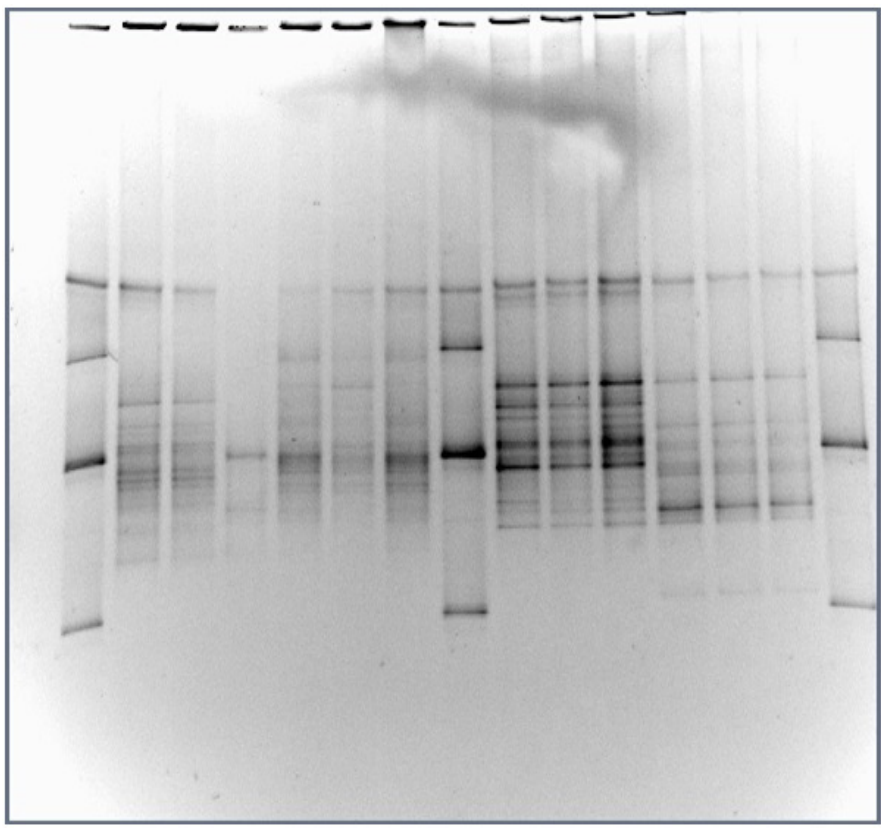

Plate 6: 20\%:80\% DGGE fingerprints of PCR-amplified region GCV6 -V8F and V6-V8R $16 S$ rDNA from effluent bacterial communities. Lanes:1, 7 and 15,marker;24,effluent samples from clarifier;5,6 and 8samples from river;9-11,samples from processed water and lanes 1214 ,samples from retention pond gate.

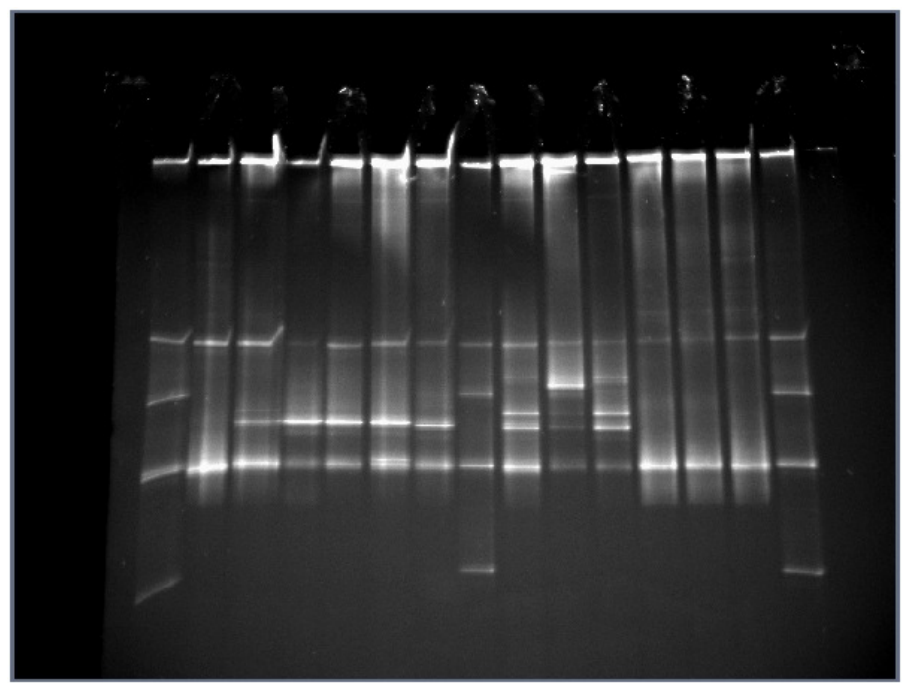

Plate 7: $20 \%: 80 \%$ DGGE fingerprints of PCR- amplified region GCV6 -V8F and V6-V8R 16SrDNA of bacterial isolates from petrochemical industrial effluent.Lanes:1, 7 and 15, marker;2 ,Enterobacter,3, Bacillus;4, Bacillus;5, Bacillus;6, Bacillus; 8, Enterococcus; 9, Lactobacillus;10, Enterococcus;11, Pseudomonas; 12, Streptococcus;13, Staphylococcus and14, Staphylococcus.

\subsection{Re-amplified PCR products (V6V8F and V6V8R) of DGGE Bands for Sequencing}

Plates 8 and 9 shows the images of PCR products on $1 \%$ ethidium bromide agarose gel of bacterial community from petrochemical industrial effluent from DGGE bands excised for sequencing. Fig 8 depicts excised bands of isolates from clarifier and receiving river while Fig 9 depicts cut bands from process wastewater and retention pond gate. They all had the required base pair of 500 .

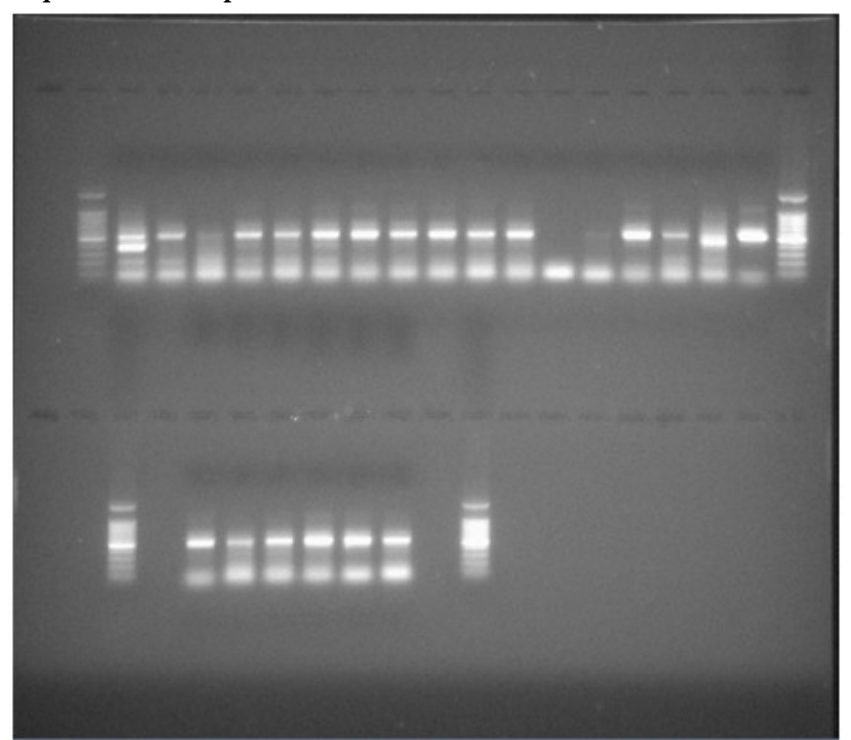

Plate 8: V6-V8 region of PCR products of bands excised from DGGE fingerprints of petrochemical industrial effluent stained with ethidium bromide on $1 \%$ agarosegel.Lanes: 1, 19, 20 and 27, 100bp DNA ladder; 216 bacteria community in clarifier; 17 , positive control; 18, blank; 21-26, bacterial community from receiving river. 
DEContaminating Eleme PetrochemiCAl InduSTRIAL EFFLuENT USING 16S RDNA PCR GeL C. U. Ajuzie \& E. I. Atuanya



Plate 9: V6-V8 region of PCR products of bands excised from DGGE fingerprints of petrochemical industrial effluent stained with ethidium bromide on 1\% agarose gel.Lanes:1,20,21 and 39,100bp DNA ladder; 2-19, 22-25 bacterial community in process wastewater;2636, bacterial community from retention pond 37,positive control and38 blank.
3.3 Dendrograms and similarity matrices of DGGE gels of petrochemical industrial effluent and bacterial isolates

Figure 1 shows the dendogram and similarity matrixes for bacterial community in petrochemical industrial effluent.

\section{4: Comparative sequence analysis for DGGE bands} obtained from petrochemical industrial effluent bacterial community

Tables 1 and 2 depicts the results of basic local alignment search tool(BLAST) for DGGE bands excised from the various sampling points petrochemical industrial effluent and receiving river. The similarities of the bacterial $16 \mathrm{~S}$ rDNA sequences with published data ranged from $97 \%$ to $100 \%$.The organisms retrieved from process wastewater samples (Table1) included the following bacterial species: Enterococcus durans, Enterococcusfaecalis, Pseudohobacterincheonensis, Roseococcussp and uncultured bacilli. Retrieved bacterial species from Clarifier include; Lactobacilluscasei and Staphylococcus equorum; Retention pond gate with the organisms Staphylococcus equorum, uncultured freshwater bacterium and uncultured Lactococcus. Receiving river had Providenciavermicola, Enterococcusfaecium, Lactococcuslactis and Lactobacillusplantarum (Table 2)

\section{DGGE bacteria}

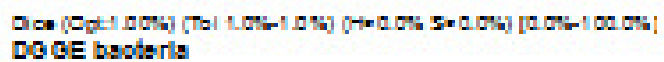

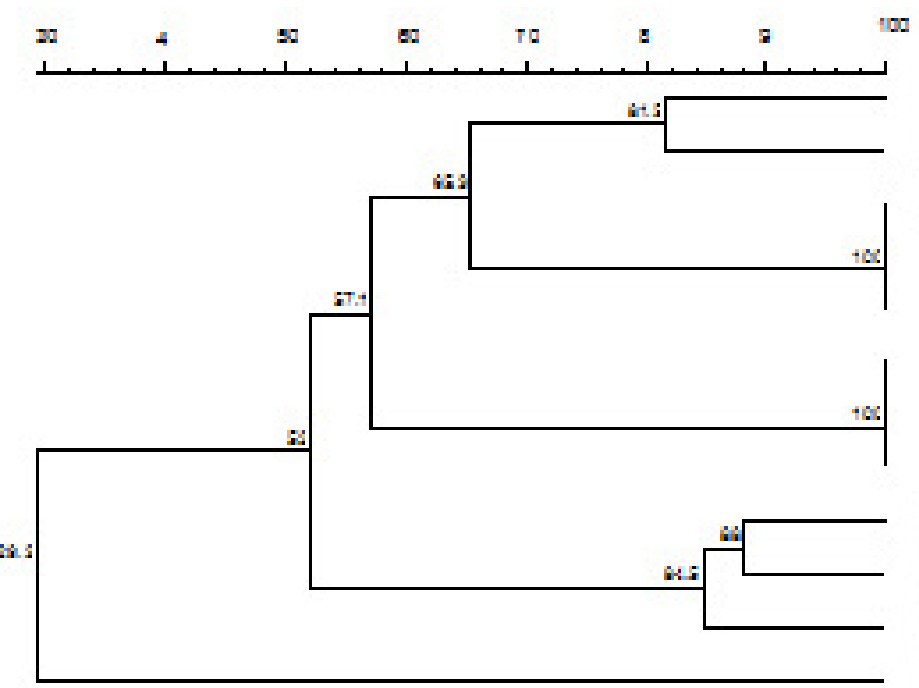

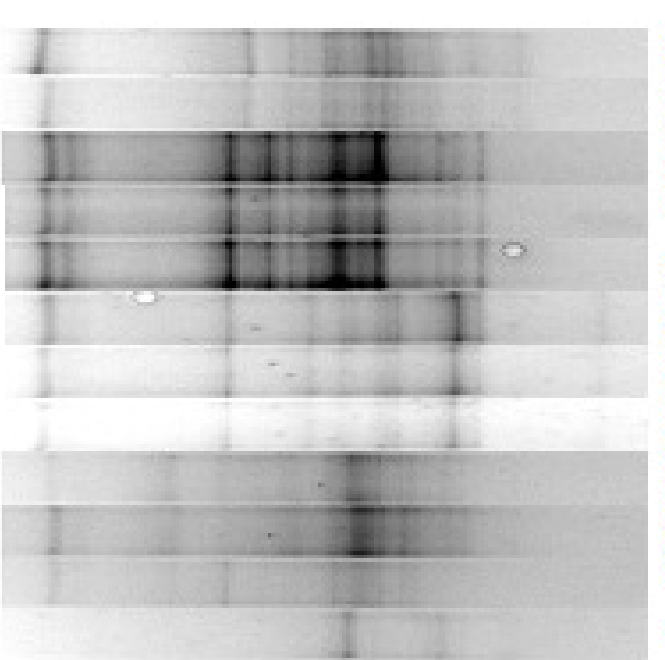

CW1

Figure 1: Dendrogram showing the relationship between bacterial communities from the different sampling points of petrochemical industrial effluent and receiving river.

Key: CW-Clarified water; PW-Process wastewater; RP-Retention pond gate; RR-Receiving river 
Decontaminating Eleme Petrochemical Industrial EfFluent using 16S RDNA PCR Gel $\quad$ C. U. Ajuzie \& E. I. Atuanya

Table1: Sequence similarity of excised DNA fragments of process wastewater bacterial community from the bacterial

\begin{tabular}{|c|c|c|c|c|}
\hline \multicolumn{5}{|c|}{$16 S$ rDNA clone library. } \\
\hline $\begin{array}{l}\text { Sampl } \\
\text { e ID }\end{array}$ & Closest Relative & $\begin{array}{l}\text { Accession } \\
\text { number }\end{array}$ & $\begin{array}{l}\% \\
\text { Similarit } \\
\mathrm{y}\end{array}$ & Sequence \\
\hline PWW & $\begin{array}{l}\text { Enterococcussp } \\
\text { Enrichment Culture clone } \\
\text { AVCTGRB10A }\end{array}$ & $\begin{array}{l}\text { HM346202. } \\
1\end{array}$ & $99 \%$ & $\begin{array}{l}\text { CGAGCACGCCGCGTGAGTGAAGAAGGTTTTCGGATCGTAAAACTCTGTTGT } \\
\text { TAGAGAAGAACAAGGACGTTAGTAACTGAACGTCCCCTGACGGTATCTAACCAGAA } \\
\text { AGCC } \\
\text { ACTAACTACGTGCGAGCAGCCGCGGTAATAAAGCTGGCT }\end{array}$ \\
\hline & $\begin{array}{l}\text { Uncultured Bacilli } \\
\text { Bacterium Clone } \\
\text { MS166A1_D09 }\end{array}$ & EF700564.1 & $99 \%$ & $\begin{array}{l}\text { AGAAAGTTTTCGGATCGTAAAACTCTGTTGTTAGAGAAGAACAAGGATGAGAGTAA } \\
\text { CTGT } \\
\text { TCATCCCTTGACGGTATCTAACCAGAAAGCCACGGCTAACTACGTGCGAGCAGCCGC } \\
\text { GGT } \\
\text { AATAAAACC }\end{array}$ \\
\hline & $\begin{array}{l}\text { Enterococcusdurans Strain } \\
\text { R0-37 }\end{array}$ & $\begin{array}{l}\text { HQ603863. } \\
1\end{array}$ & $99 \%$ & $\begin{array}{l}\text { GCGAACGGGTGAGTAACACGTGGGTAACCTGCCCATCAGAAGGGGATAACACTTGG } \\
\text { AAAC } \\
\text { AGGTGCTAATACCGTATAACAATCGAAACCGCATGGTTTTGATTTGAAAGGCGCTTT } \\
\text { CGG } \\
\text { GTGTCGCTGATGGATGGACCCGCGGTGCATTAGCTAGTTGGTGAGGTAACGGCTCAC } \\
\text { CAA } \\
\text { GGCCACGATGCATAACCGACCTGAGAGGGTGATCGGCCACATTGGGACTGAAACACA } \\
\text { GCC }\end{array}$ \\
\hline & $\begin{array}{l}\text { Enterococcus faecalis } \\
\text { Strain } 45689\end{array}$ & JF903802.1 & $99 \%$ & $\begin{array}{l}\text { TATAATGCAGTCGTACGCTTCTTTTTCCACCGGAGCTTGCTCCACCGGAAAAAGAAG } \\
\text { AGT } \\
\text { GGCGAACGGGTGAGTAACACGTGGGTAACCTGCCCATCAGAAGGGGATAACACTTG } \\
\text { GAAA } \\
\text { CAGGTGCTAATACCGTATAACAATGGACA }\end{array}$ \\
\hline & Rhodobactersp AM1R2 & JN597282.1 & $97 \%$ & $\begin{array}{l}\text { GGTCTTTCTTTCGGCTGGATCCACACAGGTGCTGCATGGCTGTCCTCAGCTCGTGTC } \\
\text { GTG } \\
\text { AGATGTTCGGTTAAGTCCGGCAACGAGCGCAACCCACGTCCCTAGTTGCCAGCATTC } \\
\text { AGT } \\
\text { TGGGCACTCTAGGGAAACTGCCGATGATAAGT }\end{array}$ \\
\hline & Roseococcussp LW5 & $\begin{array}{l}\text { FM956480. } \\
1\end{array}$ & $100 \%$ & $\begin{array}{l}\text { TGGTGCCCGCAAGGGAACGACAAGACAGGTGCTGCATGGCTGTCGTCAGCTCGTGTC } \\
\text { GTG } \\
\text { AGATGTTGGGTTAAGTCCCGCAACGAGCGCAACCCTCGCCTCTATTTGCCAGCATGT } \\
\text { TTG } \\
\text { GGTGGGCACTCT }\end{array}$ \\
\hline & $\begin{array}{l}\text { PseudohobacterIncheonen } \\
\text { sis Strain KOPR1 }\end{array}$ & $\begin{array}{l}\text { GU322906. } \\
1\end{array}$ & $97 \%$ & $\begin{array}{l}\text { GGTCTTTCTTTCGGCTGGATCCACACAGGTGCTGCATGGCTGTCCTCAGCTCGTGTC } \\
\text { GTG } \\
\text { AGATGTTCGGTTAAGTCCGGCAACGAGCGCAACCCACGTCCCTAGTTGCCAGCATTC } \\
\text { AGT } \\
\text { TGGGCACTCTAGGGAAACTGCCGATGATAAGT }\end{array}$ \\
\hline
\end{tabular}

Key: PWW-Process wastewater

Table1: Sequence similarity of excised DNA fragments of clarified water and retention pond bacterial community from the bacterial $16 S$ rDNA clone library.

\begin{tabular}{|c|c|c|c|c|}
\hline $\begin{array}{l}\text { Sampl } \\
\text { e ID }\end{array}$ & Closest Relative & $\begin{array}{l}\text { Accession } \\
\text { number }\end{array}$ & $\begin{array}{l}\% \\
\text { Similari } \\
\text { ty }\end{array}$ & Sequence \\
\hline \multirow[t]{2}{*}{ CW } & $\begin{array}{l}\text { Lactobacilluscasei } \\
\text { Strain } 095\end{array}$ & $\begin{array}{l}\text { JN } \\
560879.1\end{array}$ & $99 \%$ & $\begin{array}{l}\text { GCTATACATGCAGTCGTACGCTTCTTTTTCCACCGGAGCTTGCTCCACCGGAAAAAGAAG } \\
\text { AGTGGCGAACGGGTGAGTAACACGTGGGGAACCTGCCCATCAGAAGGGGATAACACTTGG } \\
\text { AAACAGGTGCTAATACCGTATAACAATCGAAACCGCATGGTTTTGATTTGA } \\
\text { AAGGCGCT }\end{array}$ \\
\hline & $\begin{array}{l}\text { Staphylococcusequo } \\
\text { rum Strain SS13 }\end{array}$ & $\begin{array}{l}\text { AY126195 } \\
.1\end{array}$ & $99 \%$ & $\begin{array}{l}\text { GATAGGTACCGTCAGATGTGCACAGTTACTTACACATTTGTTCTTCCCTAATAACAGAGT } \\
\text { TTTACGATCCGAAAACCTTCATCACTCACGCGGCGTTGCTCCGTCAGACTTTCGTCCATT } \\
\text { GCGGAAGATTCCCTACTGCTGCCTCCCGTAGGACGACTTC }\end{array}$ \\
\hline \multirow[t]{3}{*}{$\mathrm{RP}$} & $\begin{array}{l}\text { Uncultured } \\
\text { Freshwater } \\
\text { Bacterium clone } \\
\text { 27PVC }\end{array}$ & $\begin{array}{l}J F 277898 . \\
1\end{array}$ & $100 \%$ & $\begin{array}{l}\text { CTGCACACAGGTGCTGCATGGCTGTCGTCAGCTCGTGTCGTGAGATGTTGGGTTAAGTCC } \\
\text { CGCAACGAGCGCAACCCTTGCCATCAGTTGCTACGAAAGGGCACTCTGATGGGACTGCCG } \\
\text { GTGACAAACCGGAGGAAGGTGGGGATGACGTCAAGTCCTCATGGCCCTTATAGGTGGGGC } \\
\text { TACACACGTCATACAA }\end{array}$ \\
\hline & $\begin{array}{l}\text { Uncultured } \\
\text { Lactococcus }\end{array}$ & $\begin{array}{l}\text { GQ365748 } \\
.1\end{array}$ & $100 \%$ & $\begin{array}{l}\text { TAGTTACCGTCACTTGATGAGCTTTCCACTCTCACCAACGTTCTTCTCTACCAACAGAGT } \\
\text { TTTACGATCCGAAAACCTTCTTCACTCACGCGGCGTTGCTCGGTCAGACTTTCGTCCATT } \\
\text { GCCGAAGATTCCCTACTGCTGCCTCCCGTAGGAACGGTGCG }\end{array}$ \\
\hline & $\begin{array}{l}\text { Staphylococcusequo } \\
\text { rum strain SDMRI I }\end{array}$ & $\begin{array}{l}\text { AY126195 } \\
.1\end{array}$ & $99 \%$ & $\begin{array}{l}\text { GATGTGAACAGTTACTTACACATTTGTTCTTCCCTAATAACAGAGTTTTACGATCCGAAA } \\
\text { ACCTTCTTCACTCACGCGGCGTTGCTCCGTCAGACTTTCGTCCATTGCGGAAGATTCCCTACTGCT } \\
\text { GCCTCCCGTAGG }\end{array}$ \\
\hline
\end{tabular}


Table2: Sequence similarity of receiving river bacterial community of $16 S$ rDNA from $16 S$ rDNAclone library

\begin{tabular}{|c|c|c|c|c|}
\hline $\mathrm{RR}$ & $\begin{array}{l}\text { Uncultured Bacilli Bacterium } \\
\text { Clone MS211A1_H04 }\end{array}$ & EF710074.1 & $99 \%$ & $\begin{array}{l}\text { AGAAGTCTGACCGAGCACGCCGCGTGAGTGAAGAAGGTTTTCGGATCGTAAAACTCTGTT } \\
\text { GTTAGAGAAGAACAAGGATGAGAGTAACTGTTCATCCCTTGACGGTATCTAACCAGAAAG } \\
\text { CCACGGCTAACTACGTGCGAGCAGCCGCGGTAATTGT }\end{array}$ \\
\hline & Providenciavermicola Strain W4 & JN225414.1 & $98 \%$ & $\begin{array}{l}\text { AGGGTTGTAAAGTACTTTCAGTCGGGAGGAAGGCGTTGATGCTAATATCATCAACGATTG } \\
\text { ACGTTACCGACAGAAAAAGCACCGGCTAACTCCGTGCGAGCAGCCGCGGTAATTATGG }\end{array}$ \\
\hline & Enterococcus faecium & AB681208.1 & $99 \%$ & $\begin{array}{l}\text { GAGTCTGACCGAGCACGCCGCGTGAGTGAAGAAGGTTTTCGGATCGTAAAACTCTGTTGT } \\
\text { TAGAGAAGAACAAGGATGAGAGTAACTGTTCATCCCTTGACGGTATCTAACCAGAAAGCC } \\
\text { ACGGCTAACTACGTGCGAGCAGCCGCGGTAATAGAAG }\end{array}$ \\
\hline & Lactococccuslactis & AB602805.1 & $100 \%$ & $\begin{array}{l}\text { GTAGTTACCGTCACTTGATGAGCTTTCCACTCTCACCAACGTTCTTCTCTACCAACAGAG } \\
\text { TTTTACGATCCGAAAACCTTCTTCACTCACGCGGCGTTGCTCGGTCAGACTTTCGTCCAT } \\
\text { TGCCGAAGATTCCCTACTGCTGCCTCCCGTAGGAGCCCGTGCCCCCGCC }\end{array}$ \\
\hline & $\begin{array}{l}\text { Lactobacillusplantarum strain } \\
\text { N149 }\end{array}$ & JN792134.1 & $97 \%$ & $\begin{array}{l}\text { ATACGTGACAGTTACTCTCACATATGTTCTTCCTTAACAACAGAGTTTTACGAACCGAAA } \\
\text { ACCTTCTTCACTCACGCGGCGTTGCTCCATCAGACTTTCGTCCATTGGGGAAGATTCCCT } \\
\text { ACTGCTGCCTCCCGTAGG }\end{array}$ \\
\hline
\end{tabular}

Key: RR- Receiving water

\section{DISCUSSION}

Metagenomic DNA was extracted from bacterial isolates from petrochemical industrial effluent and bacterial community present in the effluent. The validity of this study largely depended on the extraction of representative metagenomic DNA of the microbial communities from the petrochemical industrial effluent. However, there are difficulties associated with effluent DNA extraction such as incomplete lysis, DNA adsorption to effluent surfaces, co-extraction of enzymatic inhibitors, yield loss, and degradation or damage of the DNA [9].

There is paucity of information regarding the extraction of DNA from petrochemical industrial effluent using Ultraclean $\mathrm{TM}$ Water DNA extraction $\operatorname{Kit}(0.22 \mu \mathrm{m})$. However, other extraction methods have been used to extract DNA from samples of varied origin as reported by [10].Plate 1 shows that PCR using $16 \mathrm{SF}$ and $16 \mathrm{R}$ primers and $1 \mu \mathrm{l}$ of DNA as template was not successful as only one product was observed when analyzed on agarose gels, suggesting that the primer could not enable the amplification of bacterial community from petrochemical industrial effluent. The primer V3F and V3R amplified the V3 region of the 16S rDNA giving a base pair size of 200 as seen in Fig2 using the same amount of DNA template. However, this did not agree with [8] who reported a basepair of 500 using same primer for detection of bacterial pathogens.

Strong PCR bands however were observed as shown in plate3 using V6V8F and V6V8R primers and fragments were of the expected size of $500 \mathrm{bp}$. The primers were subsequently used for DGGE analysis with GC clamp added to the forward primers as described by[4].The result indicates that V6V8F and V6V8R primers are the best for DGGE differentiation of bacterial community from petrochemical industrial effluent.

The bacterial diversity examined by a number of bands and the migration position in a DGGE gel has been used to examine bacterial diversity,for example in sausages[3] in anaerobic sludge blanket granules [12],bacterial diversity in soil[13] and dairy wetland wastewater effluent [14],however researches on DGGE bacterial community in petrochemical industrial effluent is not well documented. In this study, the application of total bacterial DGGE was used to study the diversity of bacterial communities in petrochemical industrial effluent. This approach exploited the discriminatory power of DGGE to differentiate DNA molecules on the basis of differences in their sequences [15].

Results were obtained from two different denaturant gradients in the DGGE gels (Plates 4-7) to assess the best differentiation gradient for DGGE of bacterial community in the effluent. A $20-80 \%$ denaturant gradient ratio using GCV6V8F and V6V8R primers was optimal for the differentiation of bacterial community from petrochemical industrial effluent whereas a 30 $50 \%$ denaturant gradient ratio using GCV3F and V3R had bands migrating out of the gels indicating that there was a poor differentiation. This however does not agree with [7] who reported bacterial community differentiation in cheese using the same denaturant ratio.

The results obtained in this study also show high bacterial diversity as revealed by DGGE. The DGGE patterns showed some strong bands with strong intensity which represents a wide variety and dominant bacterial species in effluent samples. These dominant bacterial species are well adapted and play the important role of biodegradation of the effluent. The profiles obtained by the DGGE agreed with the 
results obtained by traditional methods which isolated an array of bacteria from petrochemical industrial effluents of similar composition.

DGGE band patterns from high diversity ecosystems such as marine sediments are very complex and difficult to interpret [16].Therefore, the application of advanced statistical methods is crucial. In this study, a similarity matrix, based on the presence and absence of individual bands, was calculated for the various sampling points and receiving river of petrochemical industrial effluent (fig 1).These DGGE band patterns reveal the differences in the bacterial community structures between the four sampling points. The differences between the four sampling points are considerable. For instance, the sample from process wastewater (PW) contains less similar bacteria with that of retention pond gate (57\%).The reason could be due to the different treatments applied on the effluent at different stages. The $100 \%$ similarity of the bacterial community in the same effluent sampling points further proves this. Also the DGGE band patterns of isolates using the similarity matrix shows that there was a high bacterial diversity indicating the changes on the microbial community structure attributed to the process of biological wastewater treatment of the petrochemical industrial effluent plant of study. The similarities of the bacterial $16 \mathrm{~S}$ rDNA sequences with published data ranged from $97 \%$ to $100 \%$ (Tables 18 and19). The sequence result revealed the presence of bacterial species of Pseudomonas, Enterococcus, Lactobacillus, Rhodobacter, Staphylococcus, Lactococcus, Roseococcus and uncultured bacterium. The results of the sequencing further proved the presence and ability of these organisms to biodegrade petrochemical industrial effluent into less environmentally hazardous products. The results of this study are interesting not only for the contribution to knowledge on the micro flora of petrochemical industrial effluent but also because the working application of the whole approach may represent a tool of utmost importance in ecological studies. Moreover,this kind of approach can play an important role in bioremediation of petroleum refinery and petrochemical wastewaters.

\section{REFERENCES}

[1] Chikere, B.O. and Okpokwasili, G. C. Frequency of occurrence of microorganisms at petrochemical effluent outfall sites .Journal of Tropical Bioscience. Vol.4 ,2004 ,pp.12-18.
[2] Israel, A.U., Obot, I.B., Umoren, A.U., Mckenie, V. and Ebong, G.A. Effluents and solid waste analysis in a petrochemical company. A case study of Eleme Petrochemical Company Ltd, PortHarcourt, Nigeria. E- Journal of Chemistry, Vol.5, Number 1, 2007, pp. 74-80.

[3] Cocolin, L., Manzano, M., Cantoni, C. and Comi, G. Denaturing gradient gel electrophoresis analysis of the 16s rRNA gene VI region to monitor dynamic changes in the bacterial population during fermentation of Italian sausages. Applied Environmental Microbiology,Vol.67,2001,pp. 5113-5121

[4] Muyzer, G., De Waal, E.C., and Ulitterlinden, A.G. Profiling of complex microbial populations by denaturing gradient gel electrophoresis analysis of polymerase chain reaction amplified genes coding for $16 \mathrm{~s}$ rRNA.Applied Environmental Microbiology, Vol.59,1993, pp.695-700.

[5] Stecher,B., Robbiani,R., Walker,A. W., Westendorf, A.M. and Barthel, M. Salmonella entericaserovarTyphimurium exploits inflammation to compete with the intestinal microbiota. Plos Biology, Vol. 5 Number 10, 2007, pp. 2177-2189

[6] Martin, R., Heilig, Zoethndal, E., Jimerez, E. and Fernandez, J. Cultivation independent assessment of the bacterial diversity of breast milk among healthy women. Research in Microbiology Vol.158 Number 1, 2007,pp. 31-37

[7] Ercolini, D., Hill, J.P. and Dodd, E.R. Bacterial community structure and location in cheese.Applied Environmental Microbiology.Vol.69, Number 6, 2003, pp.35403548

[8] Niannian, J., Peng, B., Wang, G., Wang, S.andPeng, $X$. Universal primer PCR with DGGE for rapid detection of bacterial pathogens. Journal of Microbiology Methods Vol.57, 2004, pp. 409-413

[9] Miller, D. N., Bryant, J. E., Madsen, E. L. and Ghiorse, W. C., Evaluation and optimization of DNA extraction and purification procedures for soil and sediment samples. Applied Environmental Microbiology Vol. 65, 1999, pp. 4715-4724.

[10] Chaudhuri, R., Pattanayak, A.K .and Thakur, A.R. Microbial DNA extraction from samples of varied origin. Current Science. Vol. 91Number12, 2006, pp. 1697-1700.

[11] Keyser, M., Witthuhn, N. and Britz, T.J. PCR based denaturing gradient gel electrophoretic evaluation of changes in the non methanogenic population of stressed upflow anaerobic sludge blanket granules. World Journal of Microbiology and Biotechnology. Vol. 22, 2006, pp. 1041-1048. 
[12] Tamar, O., Shaviv, A., Goldrath, T., Mandelbaum, R.T., and Minz, R. Influence of effluent irrigation on community composition and function of ammonia oxidizing bacteria in soil. Applied Environmental Microbiology Vol.67, Number8, 2001, pp. 3426-3433.

[13] Ibekwe, M.A., Grieve, C.M., and Lyon, S.R.. Characterization of microbial communities and composition in constructed dairy wetland wastewater effluent. Applied Environmental Microbiology Vol. 69, Number 9, 2003, pp. 50605069.

[14] Lerman, I.S., Fischer., S.G., Hurley, I., Silverstein, K. and Lumelsky, N. Sequence determined DNA separation Annual Review of Biophysics and Bioengeneering. Vol. 13 1984, pp.399-423.

[15] Boon, N., De windt, W., VerStraete, W. and Top, E.M. .Evaluation of nested PCR-DGGE (denaturing gradient gel electrophoresis) with group specific 16s rRNA primers for the analysis of bacterial communities from different wastewater treatment plant.FEMSMicrobiology and Ecology.Vol. 39 2001, pp. 101-112.

[16] Roling, W.F.M.,VanBreukelen, B.M.,Braster, M., Goeltcom, M.T., Groen, J. and Van Verseveld, H.W. Analysis of microbial communities in a landfill leachate polluted aquifer using a new method for anaerobic physiological profiling and 16S rDNA based fingerprinting. Microbial EcologyVol. 40, 2000, pp.177-188.

[17] Kowalchuk, G.A.,Stephen, J.R.,De Boer, W., Prosser, J.I., Embley, T.M. and Woldendorp, J.W. Analysis of ammonia oxidizing bacteria of the beta subdivision of the class Proteobacteria in coastal sand dunes by denaturing gradient gel electrophoresis and sequencing of PCR amplified 16S ribosomal DNA fragments. Applied Environmental Microbiology Vol.63, 1997, pp. 1489-1497

APPENDIX: DGGE PROTOCOL NOTES

PREPARATION OF REAGENTS - $0 \%$ and $100 \%$ denaturant solutions

\begin{tabular}{lcc}
\hline & $0 \%$ solution & $100 \%$ solution \\
\hline $\begin{array}{l}2 \times 250 \mathrm{ml} \text { work } \\
\text { bench }\end{array}$ & & \\
$\begin{array}{l}\text { 50X TAE } \\
\text { Urea }\end{array}$ & $4 \mathrm{ml}$ & - \\
deionised water & - & $80 \mathrm{~g}$ \\
\hline Fume cupboard & $156 \mathrm{ml}$ & - \\
\hline $40 \%$ acrylamide $/$ bis & $40 \mathrm{ml}$ & $40 \mathrm{ml}$ \\
$\begin{array}{l}\text { Formamide } \\
\text { (deionised) }\end{array}$ & - & $80 \mathrm{ml}$ \\
$\begin{array}{l}\text { Make up to } 200 \mathrm{ml} \\
\left.\text { (deionised } \mathrm{H}_{2} \mathrm{O}\right)\end{array}$ & - & - \\
Total Volume & & \\
\hline
\end{tabular}

